\title{
Factors Affecting Debt Policy on LQ-45 Company in Indonesia Stock Exchange Period 2015 - 2018
}

\begin{abstract}
Handaru Indrian S Adi
Universitas PGRI Ronggolawe

Corresponding author. Email: handaru.indriansa89@gmail.com

ABSTRACT

This research is intended to determine whether there is influence of Ownership variables Managerial, Institutional Ownership, Profitability, Asset Structure, Company Size, and Business Risk on Debt Policy on company LQ-45 Nonfinancial which is listed on the Indonesia stock Exchange. Based on the results of the data analysis, the results of testing the regression, the results of testing in a partial showing the variable Ownership is Managerial, the variable Profitability has a negative influence and significant against the Policy Debt at the enterprises of the LQ-45 Non-Financial period 2015 - 2018, Variable Ownership Institutional class, a variable of measurement of the enterprise, the variable Risk does not have influence on the Policy Debt at the enterprises of the LQ-45 Non-Financial period 2015 - 2018, while the Variable for the Structure of Assets has a positive influence on Debt Policy on company LQ-45 Non-Financial period 2015 - 2018. Testing the coefficient of determination is known the proportion of contribution of the variable of Ownership of Managerial, Institutional Ownership, Profitability, Asset Structure, Company Size, and Business Risk on Debt Policy on company LQ-45 in Indonesia stock Exchange amounted to 31.5 percent.
\end{abstract}

Keywords: ownership structure, profitability, company size, business risk and debt policy

\section{INTRODUCTION}

To be able to carry out the activities of the operational business, every enterprise has different needs especially related to the fund so that the activity of the enterprise is able to run as it should. Funds are always needed to cover the whole or part of the fee required, good long-term funds and short-term funds. Funds are also needed to do the expansion of effort or investment the new. It means inside the company must be available funds in the amount of certain up available in times of need. In this case the tasks of the manager of finance the duty to satisfy the needs of the funds.

In the practice of the enterprise to meet the shortfall will need its funds, the company has sources of funds which can be obtained from the company's internal methods of the fulfillment of the needs will be the funds originating from the internal enterprise known with the name of the method of expending its own capital (equity financing). In addition, there is also a source of neither funds from the external of the enterprise (the sale of shares, the issuance of the obligations, the sale of the securities nor the loans from the bank). The method of the fulfillment of the needs will be the funds originating from external enterprises mentioned methods expending with debt (debt financing) [1].
The results of the funding of financial enterprises related to the composition of the debt often times be the cause of conflict between management and shareholders. The conflict extends from where the source of such funds available and how funds raised will be invested. This happens because of the separation between the functions of ownership and function of the processing enterprises up to cause the onset of a difference of interests between the management with the shareholders, and this situation is often referred to with the agency conflict. Where, managers tend to prioritize self-interest of managers and shareholders do not like the interests of the manager such cause will result in the cost of the enterprise increased up to the profit received will experience a decline.

In addition, the designation of manager by the owner of the stock to manage enterprises in fact is often faced with problems because the purpose of the enterprise clashes with the purpose of a personal manager. With the authority that owned, the manager can perform actions that are more profitable for him at the expense of the interests of the shareholders as owners of the enterprise. This leads to the existence of a conflict of interest between the shareholders with the manager.

Some alternatives that can be done to reduce agency cost is by way of (1) add the possession of company shares by management until the manager will be careful in doing the recruitment decision as well as to be able to feel a direct benefit from the decisions taken, (2) the 
monitoring mechanisme in the company. One of the mechanisme of such surveillance is to improve the monitoring agent by institutional investors (3) increase funding with debt. The increase in debt will lower the agency conflict and excess cash flow available in the company up to a possible lowering of the waste by the management.

The funds collected will have an influence on the financial enterprise. When enterprises use the debt, will give rise to fee a regular form of cost of capital. The cost of this capital will be borne by the enterprises the form of interest charges that should be paid to the investor. In addition, when a company uses the sources of funds from internal will give rise to opportunity cost. Therefore, the manager of finance should be carefully in doing the accumulating funds. Not careful in collecting funds will add to the cost of capital borne by the company as well as have an impact on the lack of profitability of the company [2].

Financing with debt has an influence for the enterprises because of debts have the burden of a permanent nature. The failure of the company in paying interest on debt can cause financial trouble that could end with bankruptcy of the enterprise. But, with the use of debt can provide tax breaks on the flowers of the profitable shareholders. Therefore, the use of debt should be balanced between profits and losses in enterprise's earning [3].

The selection of the object of research using the company LQ-45 Non-Financial because the shares of enterprises that enter in the calculation of the index LQ45 Non-Financial taken reflects the price movement of the stock the most actively traded and also influence the state of the market. In addition consists of stocks with liquidity and mkt market of high as well as have the growth prospects and the financial condition is good enough. Besides enterprises in in the calculation of LQ45 Non-Financial expected can represent any other company listed on the Indonesia Stock Exchange.

The purpose will be achieved in this research is to:

1. To Analyze the influence of Ownership Managerial toward Policy Debt on the Company LQ-45 NonFinancial in Indonesia Stock Exchange period 2015 2018.

2. To Analyze the influence of Ownership Institutional class against the Policy of Debt on the Company LQ45 Non-Financial in Indonesia Stock Exchange period $2015-2018$.

3. To Analyze the influence of Profitability against the Policy Debt at the Enterprises of the LQ-45 NonFinancial in Indonesia Stock Exchange period 2015 2018.

4. To Analyze the influence of the Structure of Assets against the Policy Debt at the Enterprises of the LQ45 Non-Financial in Indonesia Stock Exchange period $2015-2018$.

5. To Analyze the influence of the Dimensions of the Enterprise against the Policy Debt at the Enterprises of the LQ-45 Non-Financial in Indonesia Stock Exchange period $2015-2018$.

6. To Analyze the influence of the Risk of Business against the Policy Debt at the Enterprises of the LQ45 Non-Financial in Indonesia Stock Exchange period $2015-2018$

\section{LITERATURE REVIEW}

Harjito and Martono [4] noted the policy debt in the enterprise is a policy associated with the capital structure in the enterprise. Capital structure is the comparison of the funding of long-term enterprise that is provided by the comparison of long-term debt against the capital itself.

Dananti and Nany [5] there are several components of capital structure which consists of:

1). Long-Term debt, which is debt that the time of falling of the repayment due more than 10 years. Longterm debt consists of two components namely the debt of the mortgage and the obligations. Debt mortgage is a form of long-term debt secured by assets does not move such as land and buildings with flowers term time and manner of payment of certain. Whereas the obligations are the certificates showing the acknowledgment that enterprises borrow money and agree to pay it back within a certain timeframe.

2). Own capital, Consisting of shares preference and common stock. Shares preference is the shape of the components of long-term capital which consists of combination between the own capital with long-term debt, while common stock is the form of the components of capital long-term implanted by the investors, where the owner of this stock, by having shares means he bought the prospect and ready to bear the risk of big funds that were implanted.

The target capital structure (capital structure leverage) an enterprise defined as acceptable capital structure that will optimize the company's stock price. To decide the capital structure that is optimal typically the enterprise will study the situation, determine the target capital structure with the form of figures, e.g. $45 \%$. If the enterprise has a ratio of debt actual below the floor target, the enterprise will collect capital by issuing debt, but when the ratio of the actual above floor targets then the company will use the equity [6].

The determination of the capital structure will involve the exchange between the return and the risk will be accepted. The use of debt with large amount can increase the amount of risk that will be borne by the shareholders.

\section{a. Agency Theory}

Agency theory is a theory that arises because of an agency relationship in a company. An agency relationship is a contract, whether explicit or implicit, 
where one or more people (called principals) Ask someone else (referred to as an agent) to take action on the principal's behalf. A potential agency problem occurs when the manager of a company has an ordinary share of ownership of less than 100 percent in the company.

In this study using the theory of agency because it is able to explain the influence of managers on debt policy. The theory of agency explains with the increased ownership of shares by managers can be control over the emergence of agency costs as a result of a mechanism to minimize the conflicts of agency that occurs to the owner of the company with the manager. The improvement manager will be ownership of such shares will be aligning the interests of management with shareholders. With such methods, the manager will feel the benefits directly on the decisions taken with real and felt loss as a result of the selection process results confused.

\section{b. Signalling Theory}

With the advent of the theory of signalling to account for the fact that people inside the company basically owns the information better and quicker relates to investors of the other. In the theory of signalling developed assuming the availability of asymmetry information between the manager and the shareholders.

This Model appears based on the idea that the company manager whose financial prospect is really good is not able to convey reliable information to the investor at no cost, because delivering information from a good company will be imitated by a company whose prospects are not good.

Investors know that a disqualified company will be encouraged to convey information as information submitted by a good prospect, the investor will not trust the announcements about Company prospects. As a consequence the company will be the same prospect in the eyes of investors, there is nothing more compared to the other.

The theory of signal close relation with the theory of asymmetric information. According to Hanafi (2012), the theory of asymmetric information says that the parties of the manager in the enterprise have the same information about risk as well as the prospects of the enterprise. A certain party which is the manager of the enterprise knows how the condition of the enterprise, while investors have very little information. Therefore, the manager and the investors will happen to the asymmetry of information. Investors see the prospects and risks of the enterprise from the behavior of the manager.

\section{c. Trade-Off Theory}

According to Hanafi [8], the trade-off theory is a theory of incorporation between the Modigiliani-Miller theory by entering the cost of bankruptcy and agency fees to indicate trade-offs between tax savings from debts with bankruptcy costs.
Theory of the Modigiliani-Miller (theory MM) is a theory which says that enterprises that use debt will benefit from the tax. The theory of MM's organize enterprises to use abundance of debt. Then, came the theory of trade off which states enterprises not only to increase the debt, but there should be consideration such as the risk of bankruptcy facing the enterprise and the cost of agency.

The basic assumption in trade off theory is that there is asymmetric information explaining the decision of the capital structure taken by a company, i.e. information owned by the management of a company in which the company can convey Information to the public. A company will be on the optimal capital structure if there is a balance between the profit of tax shield of leverage with financial destress and agency cost of leverage.

\section{d. Pecking Order Theory}

Husnan [7], stated based on the company's brief theory of Duck order prefers internal funding sourced from the proceeds of operations of the company's profit withheld from the funding from external Sourced from first to issue bonds, then followed by securities that characterizing options such as bonds and conversions, and if all of these are not sufficient then the new shares are issued. This happens because of the transaction cost in obtaining funds from external parties.

Hanafi [8], stated the theory of pecking order explains why the enterprise has a floor high profitability it has a level debt smaller. Level of debt that small is not caused by the company has a target debt are small, but because they don't need funds from external enterprises. Floor high profits make funds internal enough to meet the needs of the investment.

Husnan [7], stated with the advent of the publication of the new shares will lower the value of the price of the old stock. Then in the issuance of new shares this make the manager worried that this raises the signal to shareholders that the availability of this publication will be judged bad, and can cause information asymmetry.

So, from the theory of duck order it can be concluded that in the financing of capital there is the sequence based on the risk, first the company will use the internal funds in advance that the risk is smaller, then the funding from the outside or external Which includes issuing bonds that are not at risk, and then issuing risky bonds such as conversion bonds and ultimately issuing new stocks that are far greater at risk [7].

Factors affecting the debt policy among others [9]:

a. Interest rate. The current interest rate will affect planning for capital needs to select the type of capital what will be taken, whether the company.

b. Stability of Earning. The stability and magnitude of the earning obtained by the enterprise will determine 
what the company is allowed to take a capital with a fixed load or not. Enterprises that have earning stable will always meet the obligations of the financing as a consequence of using long-term debt.

c. Composition of Assets. On the company and industry is largely embedded in its capital assets will thus give priority to the fulfillment of the capital requirements from its own capital, while capital from long-term debt only as a complement. The rules of the structure of the financial conservative horizontal stated that the number of own capital should be able to cover total fixed assets plus other assets that are permanent.

d. Risk level of assets. The magnitude of Level of risk from each of the assets of the enterprise is not the same amount, the longer time using an assets in the enterprise then the greater the amount of risk. With the advent of the Principle aspects of the risk in expending the enterprise states that when there are assets that are aware of the risks, then the enterprise should be more to do with their own capital, and reduce expenses with the capital from long-term debt.

e. Amount of capital required. The abundance of the amount of capital it takes has an influence on the type of capital that will be used. When the amount of capital needed can be met from one source, then no need to find other sources. On the contrary when the amount of capital needed is very large, and then the enterprises should remove some of the securities in together.

f. Capital market conditions. The capital market is often subjected to changes due to conjuncture waves or heaving waves. In general, when the rise - swing waves of investors are more interested in investing in stocks.

g. The Nature of Management. The natures of management have a direct influence to take the results of the fulfillment of the needs of the fund. A manager who characteristically optimistic, looked at his future with a brighter, have the courage to bear great risks (risk seeker) will be more dare to finance the growth of the sale with funds derived from debt (debt financing) even though expenses with debt gives the load financially.

h. The size of a company. A large enterprise that owns the shares spread wide, each expansion of the capital shares then will only influential small against the possibility of the loss of surveillance from the dominant towards the company.

Debt policy in a company which is a policy that deals with capital structure which is affected by asset structure (asset structure), growth in assets (asset growth), maintainability labaan (profitability), risk (risk), firm size (size), tax (tax shields), the ownership structure of company (ownership/system affiliation), the system of payment from the consumer (payment system), and market conditions (market conditions) [2].

Based on these theories, this research takes several factors affecting the company's debt policy, namely Managerial ownership, institutional ownership, profitability, asset structure, company size and risk Business.

\section{Ownership of Managerial}

Possession of managerial is the owner of the shares from the management who actively follow in the recruitment decision. With the availability of ownership is managerial will be aligning the interests between management and owners of the stock, so the manager will feel the direct benefit from the decision taken with the right and feel the losses when the decision taken is wrong about the debt. Until the manager will be very careful in managing the enterprise and will minimize the cost of agency to enhance the value of the enterprise. In this case the ownership is managerial to be influential in the negative against the policy debt in the enterprise.

\section{Institutional ownership}

Ownership of Institutional class is the ownership over the shares of the enterprise owned by the institution or the board. Possession of the institutional act as the party watching over the company. Getting high with the advent of the possession of the institution then the more efficient in the utilization of the assets of the enterprise which hopefully also will be able to act as a prophylactic against the waste of done management.

\section{Profitability}

Companies with a high return on assets rate, generally use relatively little debt. This is due to the high return on assets, making it possible for the company to conduct capital with retained earnings only. But not only that, other assumptions say with a high return on assets, meaning that the net profit that the company has high, so if the company is using large debts will not affect the structure of capital, because The company's ability to pay interest remains also high. A high return rate allows financing most of the funding needs with funds generated internally. This is in line with duck order theory suggesting that companies tend to use as many internal funding sources as possible before deciding to owe [10].

\section{Company size}

The size of the company (size) can be used as a proxy uncertainty against the state of the company in the future. Total Assets is considered able to show the size of the company because it represents the company's wealth both fixed assets and current assets. 


\section{Asset structure}

Asset structure is a comparison of fixed assets with total assets owned by the company [11]. Asset structure affects financing sources through several ways. Companies that have long-term fixed assets many use long-term mortgages payable especially if the demand for products is very convincing. Companies, whose activities are mostly seamless assets, are not so dependent on longterm debt financing and are more dependent on shortterm financing [12].

Fixed assets can be used as collateral for debt lending, and therefore can reduce the cost of financial distress and this will further increase the level of debt that can benefit the company [13]. The value of liquidation of fixed assets will usually be higher than the intangible assets (intangible assets), so that when the company has been bankrupt, the cost of financial distress incurred by smaller companies than if the company has higher intangible assets [14].

Tangible assets will demonstrate the company's ability to provide higher assurance, so assuming all other factors are constant, and the company will increase the debt to benefit from users Debts [15]. In general, companies that have collateral against debt will be more easily payable than those who have no guarantee on debt [16].

\section{Business Risk}

Business risk is a risk from the company when unable to cover its operational costs and is affected by the stability of revenues and costs. Companies with high business risk tend to avoid funding by using debts compared to companies with lower business Risk [17]. The investment world recognizes the risk of business as part of premium risk, which translates to the uncertainty of revenue streams caused by the nature of the business itself such as products, customers and the way the product is earning [18].

Companies with a highly volatile cash flow will realize that the full risk of debt will be less profitable than equity, so the company is forced to use equity to meet the company's funding To avoid financial distress [19]. Therefore, business risk has an influence on the capital structure. According to trade off theory, the higher the likelihood of financial distress (financial difficulties), the higher the possibility of financial distress costs (the cost of financial difficulties) to be borne by the company. This will cause the optimum level of debt use to be lower, so the company should use less debt.

\section{METHODS}

\subsection{Population and samples}

This research Population is the entire enterprise that has been go public in Bursa Efek Indonesia period 2015-
2018. As for the criteria used to select the sample by using the technique of purporsive sampling is as follows:

a. Enterprises that enter in the research is the enterprise of LQ-45 Non Financial that have been go public in Indonesia stock Exchange during 20152018.

b. Companies reported financials in quick succession during the period of research.

c. The company has never experienced a delisting on the stock exchange during the study period.

d. The enterprise is still actively operating for a period of research.

Enterprises which included in LQ-45 Non-Financial that have been go public in the Indonesia stock Exchange during 2015-2018 that meet the criteria amounted to 39 enterprises of the sample observations every year or in total amounting to 45 of the enterprise.

\subsection{Data Types and sources}

The data used is secondary data, which is the type of data obtained indirectly from the main source (the company). The data in this study in the form of financial report go public listed on the Indonesia Stock exchange period from 2015-2018 which becomes the object of research and other data related to the research.

The Data used in this research is financial statement data on listed companies in Indonesia stock Exchange year period 2015 - 2018, which is obtained from the data report the Financial Report are taken from the Indonesia stock Exchange Corner in FE UII, Indonesian Capital Market Directory (ICMD) and partly obtained from the data report the financial report was taken from the corner of the Indonesia stock Exchange, journal-research journal, and other sources that are relevant as supporting data.

\subsection{Operational definition of a variable}

The variables used in this study are the Ownership of Managerial, Institutional Ownership, Profitability, Asset Structure, Company Size, Business Risk and Debt Policy.

\subsubsection{Debt Policy}

Policy Debt in this research use proxy Debt to Equity Ratio (DER). Debt to Equity Ratio is a comparison between a ratio of liability against the capital itself. The ratio is used to measure how big the enterprise is financed by debt compared with their own capital.

\subsubsection{Possession of Managerial}

Possession of managerial's ownership of stock of the enterprise by the managers who actively partake in decision making in the enterprise.

\subsubsection{Ownership Institutional}


Ownership of Institutional class is the ownership over the shares of the enterprise owned by the institution or the board. Possession of the institutional act as the party watching over the company. Getting high with the advent of the possession of the institution then the more efficient in the utilization of the assets of the enterprise which hopefully also will be able to act as a prophylactic against the waste of done management.

\subsubsection{Profitability}

In this study using a profitability ratio that shows the profit in relation to investment, namely ROA (return on assets). ROA is the ratio of profit after tax with total assets.

\subsubsection{The Structure of Assets}

In this study the structure of assets will be proxies by the ratio of fixed assets owned by the company as collateral to the total assets.

\subsubsection{Company Size}

Table 1. Descriptive Statistical Variables Research Descriptive Statistics

\begin{tabular}{|c|c|c|c|c|c|}
\hline & $\mathrm{N}$ & Min & Max & Mean & Std Deviation \\
\hline $\begin{array}{l}\text { Ownership } \\
\text { Managerial }\end{array}$ & 45 & 0.00 & 15.95 & 1.2659 & 3.53011 \\
\hline $\begin{array}{l}\text { Ownership } \\
\text { Institutional }\end{array}$ & 45 & 19.45 & 85.00 & 61.3050 & 15.17246 \\
\hline Profitability & 45 & 2.05 & 40.38 & 15.1007 & 9.48731 \\
\hline Assets Structure & 45 & .2036 & 5.3698 & .642483 & .5814123 \\
\hline Company size & 45 & 10.2530 & 21.8643 & 16.67915 & 1.5510675 \\
\hline Risk Business & 45 & 10.000 & 34.370 & 95.7600 & 41.93184 \\
\hline Debt policy & 45 & .1000 & 14.2900 & .978421 & 1.7467128 \\
\hline Valid N (listwise) & 45 & & & & \\
\hline
\end{tabular}

The managerial ownership variable is known to have the smallest (minimum) value of the company being a research object of $0.00 \%$ and the largest (maximum) value of $15.95 \%$. Average value (mean) of $1.26 \%$; this value shows the average share ownership of the company by the manager by $1.26 \%$. The standard deviation of $3.53 \%$ is greater than the average value; this illustrates the high variation in the company's shares ownership data by the manager.

The institutional ownership variable is known to be the smallest (minimum) value of the company being a research object of $19.45 \%$ and the largest (maximum) value of $85.00 \%$. Average value (mean) of $61.30 \%$; this value shows the average company's share ownership by
A measure of enterprise is the measure or the magnitude of the owned assets of the enterprise. In this research the measure of enterprise proxied by the value of the logarithm of total assets.

\subsubsection{Business Risk}

Business risk is the risk of the company currently is not able to cover its operational costs and is influenced by the stability of revenue and costs. Companies with high levels of business risk tend to avoid funding with the use of debt compared to companies with a business risk is low [17].

\section{RESULTS AND DISCUSSIONS}

\subsection{Descriptive analysis}

Descriptive statistics of variables used to determine the characteristics of the variables used. Table 4.1 shows the descriptive statistics of variables the sample studied. the institutional party of $61.30 \%$. The magnitude of the deviation is $15.17 \%$ the result is smaller than the value of the flat powder; it resulted in a low deviation variation of data ownership share of the enterprise by the institutional.

The profitability variable is known to be the smallest value (minimum) of the company being a research object of $2.05 \%$ and the largest (maximum) value of $40.38 \%$. Average value (mean) of $15.10 \%$; This shows the magnitude of the company's effectiveness in making profits by utilizing its assets, the higher the profitability value shows the higher the profit that the company has booked. The magnitude of the deviation is $9.48 \%$ smaller than the average value; this illustrates the low deviation 
of the company's ability to generate the profits generated by the company.

Asset structure variables are known to be the smallest (minimum) value of the company being a research object of $0.20 \%$ and the largest (maximum) value of $5.37 \%$. Average value (mean) of $0.64 \%$; this value shows the average company's ability to provide a guarantee to make a debt loan using a fixed asset of $0.64 \%$. The magnitude of the deviation is $0.58 \%$ smaller than the average value; this illustrates the low ability deviation of the company LQ-45 Non-financial in providing guarantees to do debt loans using fixed assets.

The company size variable is known to be the smallest value (minimum) of the company being a research object of $10.25 \%$ and the largest (maximum) value of $21.86 \%$. Average value (mean) of $16.68 \%$; this is an overview of the size of the company that shows the big small companies that can affect debt policy. The standard deviation is $1.55 \%$ smaller than the average value, these results in a low difference measure of the enterprise from the value of the average measure of the enterprise which included in LQ-45 Non-Financial period 2015-2018.

The business risk variables are known to be the smallest (minimum) value of the company being a research object of $10.0 \%$ and the largest (maximum) value of $34.37 \%$. Average value (mean) of $95.76 \%$; this value shows the average overview of the level of business risk and the likelihood of financial distress (financial difficulties) of the company LQ-45 Non finance, the higher the average value indicates the more the higher the financial distress (Financial difficulties) LQ-45 Non-
Financial. The standard deviation is $41.93 \%$ the value of which is smaller than the average value; this causes a low deviation level of business risk and the possibility of the occurrence of financial distress.

The debt policy variables are known to be the smallest (minimum) value of the company being a research object of $0.10 \%$ and the largest (maximum) value of $14.29 \%$. Average value (mean) of $0.98 \%$; this value shows the average company's policy average in determining the funding decision to use its own capital or a long-term obligation of $0.98 \%$. The standard deviation of $1.75 \%$ is greater than the average value; this illustrates the high deviation of the LQ-45 Non-financial company to determine the funding decision or to determine the company's debt policy.

\subsection{The Classical Assumption Test}

\subsubsection{Testing Normality}

Figure 1 shows the results of testing normality using Normal P-P Plot with the regression. Test results normality with Normal P-P Plot indicates that the probability number is around a linear or straight line. This means that all the variables used in this study have random data that is distribution normally.

\subsubsection{Autocorrelation test}

Decision making there is no autocorrelation used DW test (Durbin Watson) by looking at the correlation coefficient of DW test. Calculation results with SPSS 20.0, obtained the statistical value of Durbin Watson as follows:

Table 2. Autocorrelation Test Result With Durbin-Watson Model Summary

\begin{tabular}{|c|c|c|c|c|c|}
\hline Model & $\mathrm{R}$ & $\mathrm{R}^{2}$ & Adjusted R Square & $\begin{array}{c}\text { Std. Error of the } \\
\text { Estimate }\end{array}$ & Durbin- Watson \\
\hline 1 & $0.586^{\mathrm{a}}$ & 0.343 & 0.286 & 0.7404915 & 1.842 \\
\hline
\end{tabular}

The results of the above calculations show that the value of DW-test is between the values of the $1.66 \mathrm{s.d}$ 2.34, which means that the value of DW-test amounted to 1.842 indicates no autocorrelation.

\subsubsection{Multicolinearity Test}

The results of the test of multicollinearity presented in Table 4.3 below the Results of the test of multicollinearity presented in Table 3 below:
Table 3. Multicollinearity Test Results

\begin{tabular}{|l|c|c|}
\hline \multirow{2}{*}{\multicolumn{1}{|c|}{ Model }} & \multicolumn{2}{c|}{$\begin{array}{c}\text { Collinearity } \\
\text { Statistics }\end{array}$} \\
\cline { 2 - 3 } & Tolerance & VIF \\
\hline (Constant) & & \\
\cline { 2 - 3 } $\begin{array}{l}\text { Ownership Managerial } \\
\text { Ownership Institutional } \\
\text { Profitability }\end{array}$ & .902 & 1.109 \\
\cline { 2 - 3 } Assets Structure & .915 & 1.093 \\
\cline { 2 - 3 } Company size & .623 & 1.605 \\
\cline { 2 - 3 } Risk Business & .618 & 1.618 \\
\cline { 2 - 3 } & .944 & 1.059 \\
\cline { 2 - 3 } & .971 & 1.029 \\
\hline \multicolumn{1}{|c|}{ Source: Data Results, 2019 } & & \\
\end{tabular}




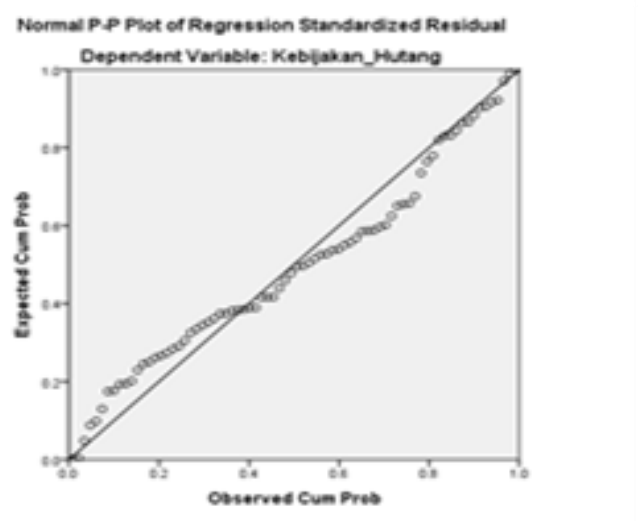

Figure 1. The Normality Test Result

The results in the table above shows that the equation of the regression model does not contain the problem of multicollinearity which means that there is no correlation between the variables-the independent variable so it can be used for subsequent analysis.

\subsubsection{Heteroskedastisity Test}

Heteroscedastisity appears when the variant of the probability distribution of interference is not constant for the entire observation over the research variables. The method used to test heteroskedastisity in this study wears a scatterplot diagram.

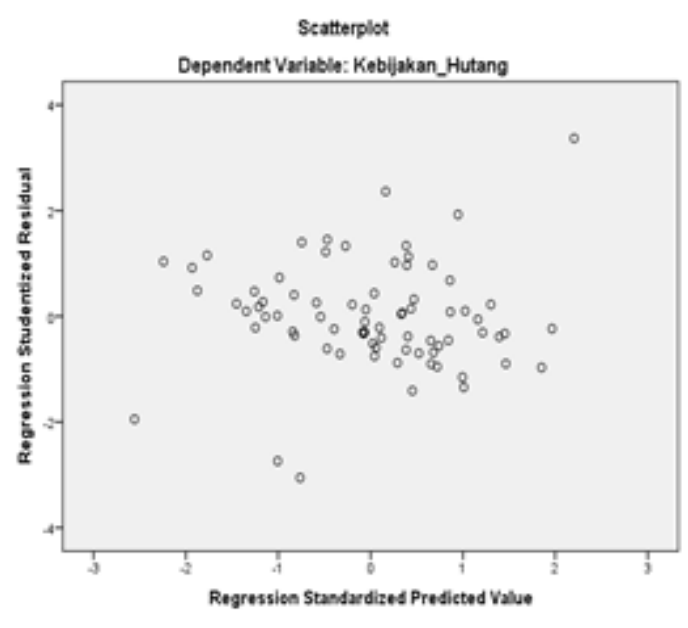

Figure 2. Heteroskedastisity Source: Data Results, 2019

In figure 2 the results show that there is no clear pattern and the points spread above and below 0 on the $\mathrm{Y}$ axis then it does not happen heteroscedasticity.

\subsection{Test Statistics $t$}

The results of the t-test can be presented in Table 4

Table 4. Test Statistics T

\begin{tabular}{|c|c|c|c|c|c|}
\hline \multirow[t]{2}{*}{ Model } & \multicolumn{2}{|c|}{$\begin{array}{l}\text { Unstandardized } \\
\text { Coefficients }\end{array}$} & \multirow{2}{*}{$\begin{array}{c}\begin{array}{c}\text { Standardized } \\
\text { Coefficients }\end{array} \\
\text { Beta }\end{array}$} & \multirow[t]{2}{*}{$\mathrm{T}$} & \multirow[t]{2}{*}{ Sig. } \\
\hline & B & Std. Error & & & \\
\hline \multirow{2}{*}{$\begin{array}{l}\text { (Constant) Kepemilikan_Managerial } \\
\text { Kepemilikan_Institusionl }\end{array}$} & 0.954 & 0.509 & & 1.874 & 0.065 \\
\hline & -0.034 & 0.026 & 0.223 & 2.222 & 0.030 \\
\hline \multirow{2}{*}{$\begin{array}{l}\text { Profitabilitas } \\
\text { Struktur_Aktiva }\end{array}$} & -0.006 & 0.006 & -0.106 & -1.038 & 0.303 \\
\hline & -3.259 & 1.431 & -0.281 & -2.277 & 0.026 \\
\hline \multirow{3}{*}{$\begin{array}{l}\text { Size } \\
\text { Risiko_Bisnis }\end{array}$} & 1.596 & 0.570 & 0.348 & 2.803 & 0.007 \\
\hline & 6.562 & 0.000 & -0.136 & -1.320 & 0.191 \\
\hline & -0.262 & 0.207 & -0.125 & -1.266 & 0.210 \\
\hline
\end{tabular}

Source: Data Results, 2019

considered constant, and then debt policy will be at 0.954 .

Based on table 4.4 multiple regression models for debt policy the factors influencing Managerial ownership, institutional ownership, profitability, asset structure, company size and business risk are as follows:

DER $=0.954-0.034 \mathrm{KM}-0.006 \mathrm{KI}-$

\subsection{ROA+1.596SA+6.562UP-0.262RISK+e}

From the above regression models can be explained that:

A. The value of the coefficient the constant of 0.954 , showing bring the independent variables are
B. Variable ownership Managerial obtained a coefficient value of 0034; this means that each Managerial ownership increase of 1 unit then causes the decline in debt policy of 0034 .

C. The institutional ownership variable obtained a coefficient value of 0.006 ; this means that every institutional tenure increase by 1 unit is causing a decline in debt policy of 0.006 .

D. The profitability variable (ROA) obtained a coefficient value of 3,259 ; this means that each 
increase in profitability (ROA) by 1 unit then causes a decline in debt policy of 3,259 .

E. Variable asset structure obtained a coefficient value of 1,596; this means that each increase in asset structure by 1 unit then causes a debt policy increase of 1,596 .

F. The variable company size produces the value of the coefficient of 6.562 , which means any increase in firm size (size) by 1 unit then causes a rise in the debt policy of 6.562 .
G. The business risk variable obtained a coefficient value of 0262 ; this means that any increase in business risk by 1 unit is causing the decline in the debt policy of 0262 .

\subsubsection{The Coefficient of Determination (R2)}

The results of multiple determination coefficients can be shown in table 5 below:

Table 5. The Coefficient of Determinant

\begin{tabular}{|c|c|c|c|c|c|}
\hline Model & $R$ & R Square & Adjusted R Square & $\begin{array}{c}\text { Std. Error of the } \\
\text { Estimate }\end{array}$ & Durbin- Watson \\
\hline 1 & $0.586^{\mathrm{a}}$ & 0.343 & 0.286 & 0.740 & 1.842 \\
\hline
\end{tabular}

From the results in Table 5 it can be concluded that the magnitude of the coefficient of multiple determination (Adjusted R2) of 0.286 . These results can be explained that the value of $28.6 \%$ the magnitude of the Debt Policy of the company is affected by six independent variables which consist of the Ownership of the Managerial, Institutional Ownership, Profitability, Asset Structure, Company Size, and Business Risk. While the results of the rest of $71.4 \%$ is influenced by other variables not included in this study.

\subsection{Discussion}

Based on the calculations of the regression analysis obtained a result that the value of Adjusted R Square as large as 0.286 indicating that Ownership of Managerial, Ownership of Institutional, Profitability, Structure of Assets, Size of the Enterprise, and the Risk of Business simultaneously have an influence on the policy debt as large as $28.6 \%$. Yet the calculation for partial profitability and ownership managerial influential in negative and significant in policy debt as well as the structure of assets influential positive and significant to the policy debt.

\subsubsection{The influence of Ownership Managerial toward a Policy of Debt}

The results In table 4.4, the variable possession of managerial show floor significance $0.030<0.05$, then it can be concluded that this variable influential negative significantly against the policy debt at the Enterprises of the LQ-45 Non-Financial period 2015-2018.The value of coefficient regression from the result of calculation of multiple regression has a negative value, which shows the higher the possession of managerial then the level of debt would be getting smaller, and vice versa.

\subsubsection{The influence of Ownership Institutional class against the Policy of the debt}

Compatible with the result of calculation of test partial on table 4.4, the variable ownership institutional class has some level of significance as big as $0.303>$ 0.05 , then it can be interpreted simply that this variable does not have significant influence against the policy debt at the Enterprises of the LQ-45 Non-Financial period 2015-2018. There is no influence on the results of this research indicate that the institutional investors have not yet believed to have better ability to monitor the actions of management compared to investors individually. In addition, the institutional parties haven't been able to do surveillance more strict and good on the part of management as well as on the company policy.

\subsubsection{Impact of profitability (ROA) on debt policy}

Testing the results on table 4.4 show, the result value significance as large as $0.026<0.05$, so it can be interpreted simply that profitability has a negative influence significantly against the policy debt at the Enterprises of the LQ-45 Non-Financial period 20152018. The value of coefficient regression from the result of calculation of multiple regression have a negative sign, which means the higher the value of profitability then the floor against the debt will be increasingly small, and vice versa

\subsubsection{Influence of assets structure on debt policy}

On the calculation results table 4.4 shows, the results of a significance value of $0.007<0.05$, so it can be interpreted that the structure of assets has a positive and significant influence to debt policy on Company LQ-45 Non-Financial-year period 2015-2018. The value of the regression coefficient from the results of the calculation of the multiple regression have a positive sign, as expected, which means it shows the great value of asset structure it will cause the debt level will be higher, and vice versa. 


\subsubsection{Effect of company size (size) on debt tracking}

Appropriate to the result of calculation test partial on the table 4.4, then, the value of the variable for size of the enterprise (size) has some level of significance as big as $0.191>0.05$, it can be concluded that the value of this variable does not have influence significantly against the policy debt at the Enterprises of the LQ-45 Non-Financial period 2015-2018. This means that the amount of debt is not determined by the great microcosm of the measurement enterprise. Enterprises-enterprises sampled in this research increase the size of company (total asset) is not only derived from the debt unless the use of funds internal (own capital) that comes from the spider.

\subsubsection{The influence of the Risk of Business against the Policy of the debt}

Appropriate to the result of calculation test partial on the table 4.4, then, the result of the value of the variable of the risk a business has a value of level significance magnitude $0.210>0.05$, then it can be explained that the value of this variable does not have influence of the value of the variable is significant against the policy debt at the Enterprises of the LQ-45 Non-Financial period 20152018 Not have the influence of the risk of business against the policy debt.

\section{CONCLUSIONS}

The influence of the Possession of Managerial have negative influence and significant on a Policy of Debt enterprises of the LQ-45 Non-Financial period 20152018. The result is because the management has cost dependents of capital incurred by the company up to the management to carry out the activity of its operating budget over the embedding minimize the cost and maximize value. So, the bigger the possession is managerial then they tend to strive to use debt in the relatively little amount as well as improve his work in the interests of the shareholders including himself.

The influence of the Possession of Institutional relations is not significant on the Policy Debt enterprises of the LQ-45 Non-Financial period 2015-2018. This is caused by the investors institutional class didn't have the confidence and a better ability to monitor the actions of management compared to investors individually. In addition, the institutional class, haven't been able to do tighter oversight of the management and policies of the enterprise debts.

The calculations yield the value of Profitability have negative influence and significant on a Policy of Debt enterprises of the LQ-45 Non-Financial period 20152018. This is because the enterprises with the level of return on assets is high, generally the use of debt in the relatively little amount.
Our calculations yield a value on the Structure of Assets has positive influence and significant on a Policy of Debt enterprises of the LQ-45 Non-Financial period 2015-2018. This is because the more assets a fixed a company, then the easier company get the funds with debt. Because the lenders will use assets fixed as a guarantee, so when the enterprise is not able to pay the debt and specified bankruptcy then the creditor will sell the assets of the to be used as the amortization of the debt.

Measurements Enterprises do not have significant influence against the Policy of Debt enterprises of the LQ-45 Non-Financial period 2015-2018. On an Enterprise which is made to be sample in this research is capable of increase the size of company (total asset) not only originated in debt than use their own capital derived from profits. The result of this research aligns with the theory of pecking order mentioned that large enterprises tend to be using funds derived from within the enterprise, which means that large enterprises tend to use debt relatively smaller.

The calculations yield the value of the Risk of the Business does not have influence significantly on the Policy Debt enterprises of the LQ-45 Non-Financial period 2015-2018. There being no influence on the risk of the business on the policy debt based on the theory of trade off, the higher the possibility of financial distress will increasingly high possibility of financial distress costs that must be borne by the company. This will cause the floor of the use of debt is optimal is getting low, until the enterprise should use a little more debt.

\section{SUGGESTION}

This research has some limitations that only use the company LQ-45 Non-financial year 2015-2018 as a research object, on the research which will come is expected to add variables to the observation type of industry or company characteristics can be more thorough so that the number of samples obtained will be more, and the type of industry can represent all the aspects of the existing company, such as financial companies and increase the sampling period can be done longer so that it is expected to add better research results.

Further studies need to connect other factors that are predicted to influence the DER in the form of macroeconomic and non-economic variables. Macroeconomic variables that may affect the DER including interest rate, rupiah exchange rate against foreign exchange and other economic conditions as well as a variable of free cash flow.

For Investors, to review again how the debt policy of the company which can be seen from the percentage ownership of management, the profitability of the company as well as the structure of assets of the company 
because with the use of debt will increase the risk for investors in the future.

\section{REFERENCES}

[1] R. P. Indahningrum, R. Handayani, Pengaruh kepemilikan manajerial, kepemilikan institusional, dividen, pertumbuhan perusahaan, free cash flow dan profitabilitas terhadap kebijakan hutang perusahaan. Jurnal Bisnis dan Akuntansi, 11(3), 189-207, 2009.

[2] Y. Prabansari, H. Kusuma, Faktor-faktor yang mempengaruhi struktur modal perusahaan manufaktur go public di Bursa Efek Jakarta. Sinergi: Kajian Bisnis dan Manajemen, 2005.

[3] Tampubolon, Ownership Share, Policy Dividends, the Characteristics of the Enterprise, Systematic Risk, Set Chance Investments, and Policy Debt, Journal of Business and Accounting, Vol. 13 No.Three, 2005.

[4] D. A. Harjito and Martono, Financial management, Issue 2, Yogyakarta: Campus Economician FE UII, 2012.

[5] K. Dananti, M. Nany, Pengujian stabilitas struktural pengaruh growth potential, earnings variability, tax shields, firm size dan profitability terhadap leverage ratio perusahaan tekstil dan garmen di Bursa Efek Jakarta sebelum dan selama krisis ekonomi. Jurnal Riset Manajemen dan Bisnis, 2(1), 1-9, 2007.

[6] E. F. Brigham and F. Houston, Financial management, translated by Dodo Suharto and Hermawan Wibowo Book One, The Eight Edition. Jakarta: Erlangga, 2011.

[7] K. Kartini, T. Arianto, Struktur kepemilikan, profitabilitas, pertumbuhan aktiva dan ukuran perusahaan terhadap struktur modal pada perusahaan manufaktur. Jurnal Keuangan dan Perbankan, 12(1), 2008.

[8] M. Hanafi, Financial management, Yogyakarta: BPFE, 2012.
[9] B, Riyanto, Fundamentals of company spending. Yogyakarta: BPFE, 2008.

[10] A. Kesuma, Analisis faktor yang mempengaruhi struktur modal serta pengaruhnya terhadap harga saham perusahaan real estate yang go public di Bursa Efek Indonesia. Jurnal Manajemen dan Kewirausahaan, 11(1), 38-45, 2009.

[11] I. M. Pandey, Capital structure, profitability and market structure: Evidence from Malaysia. Asia Pacific Journal of Economics and Business, 8(2), 78, 2004.

[12] J. F. Weston, E. C. Thomas, Manajemen Keuangan. Jilid, 2, 1999.

[13] R. Elsas And Florysiak, Empirical Capital Structure Research: New Ideas, Recent Evidence, and Methodological Issues, Discussion Paper at Munich School of Management, Munich, July, 2008.

[14] P. Gaud, E., Jani, M. Hoesli, A. Bender, The capital structure of swiss companies: an empirical analysis using dynamic panel data. Research Paper No. 68. International Center for Financial Asset Management and Engineering (FAME), 2003. Retrieved from: http://ssrn. com/abstract, 378120.

[15] Andrianto and B. Wibowo, Testing the Theory of Pecking Order on the Enterprise-Perusahaan NonFinancial LQ45 the Period 2001-2005, Entrepreneurs, No.12. December 2007.

[16] E. F. Brigham, L. C. Gapenski, Instructor's Manual to Accompany Cases in Financial Management: Directed, Non-directed, By-request Versions. Dryden Press, Harcourt Brace College Publishers, 1995.

[17] L. J. Gitman, Principles of Managerial Finance, seventeenthedition. Massachusetts: Addison-Wesley Publishing Company, 2006.

[18] F. W. Brown, M. D. Reilly, The Myers-Briggs type indicator and transformational leadership. Journal of Management Development, 2009.

[19] A. B. Setiawan, Perbankan syariah; challenges dan opportunity untuk pengembangan di Indonesia. Jurnal Kordinat, 8(1), 1-42, 2006 